IZA DP No. 4244

The Duration of Paid Parental Leave and Children's Scholastic Performance

Qian Liu

Oskar Nordström Skans

June 2009 


\title{
The Duration of Paid Parental Leave and Children's Scholastic Performance
}

\author{
Qian Liu \\ Uppsala University \\ Oskar Nordström Skans \\ IFAU, Uppsala University and IZA
}

Discussion Paper No. 4244

June 2009

IZA

P.O. Box 7240

53072 Bonn

Germany

Phone: +49-228-3894-0

Fax: +49-228-3894-180

E-mail: iza@iza.org

Any opinions expressed here are those of the author(s) and not those of IZA. Research published in this series may include views on policy, but the institute itself takes no institutional policy positions.

The Institute for the Study of Labor (IZA) in Bonn is a local and virtual international research center and a place of communication between science, politics and business. IZA is an independent nonprofit organization supported by Deutsche Post Foundation. The center is associated with the University of Bonn and offers a stimulating research environment through its international network, workshops and conferences, data service, project support, research visits and doctoral program. IZA engages in (i) original and internationally competitive research in all fields of labor economics, (ii) development of policy concepts, and (iii) dissemination of research results and concepts to the interested public.

IZA Discussion Papers often represent preliminary work and are circulated to encourage discussion. Citation of such a paper should account for its provisional character. A revised version may be available directly from the author. 


\section{ABSTRACT}

\section{The Duration of Paid Parental Leave and Children's Scholastic Performance ${ }^{*}$}

We study how the duration of paid parental leave affects the accumulation of cognitive skills among children. We use a reform which extended parental leave benefits from 12 to 15 months for Swedish children born after August 1988 to evaluate the effects of prolonged parental leave on children's test scores and grades at age 16. We show that, on average, the reform had no effect on children's scholastic performance. However, we do find positive effects for children of well-educated mothers, a result that is robust to a number of different specifications. We find no corresponding heterogeneity relative to parental earnings or fathers' education, or relative to other predictors of child performance. We find no effects on intermediate outcomes such as mothers' subsequent earnings, child health, parental fertility, divorce rates, or the mothers' mental health. Overall the results suggest positive causal interaction effects between mothers' education and the amount of time mothers spend with their children. Since the institutional context is one in which the alternative is subsidized day care, the results imply that subsidizing longer parental leave spells rather than day care reinforce the relationship between maternal education and school outcomes.

JEL Classification: $\quad$ I21, J13, J24

Keywords: maternal employment, education, human capital, cognitive skills

Corresponding author:

Oskar Nordström Skans

IFAU

Box 513

SE-75120 Uppsala

Sweden

E-mail: oskar.nordstrom_skans@ifau.uu.se

\footnotetext{
* We are grateful for comments on various versions of this paper by Olof Åslund, Ann-Zofie Duvander, Bertil Holmlund, Per Pettersson-Lidbom, Eva Mörk, Björn Öckert, Anders Stenberg, Marianne Sundström and seminar participants at IFAU and the Labour Institute for Economic Research in Helsinki. We thank Per Johansson for kindly sharing data. The paper is part of a project sponsored by the Swedish Council for Working Life and Social Research (FAS, dnr 2004-2005).
} 


\section{Introduction}

Researchers and policymakers tend to agree that the childhood environment is important for the long-term development of children. ${ }^{1}$ It is also clear that parental labor supply decisions and the ensuing day care arrangements are key parameters which affect child environment. However, while parents, and perhaps mothers in particular, are likely to be important for child development, it is not clear that more time with the parents always have positive effects on children's development. The effects are likely to depend on both the quality of care provided by parents and the quality of alternative child care options. In addition, indirect effects on parents' income, health, and fertility may affect child development in ambiguous directions.

This paper studies how extended durations of parental leave benefits affect the development of cognitive skills among the affected children. We analyze a reform that extended the duration of paid absence from 12 to 15 months of paid for Swedish children born after August 1988. In Sweden, the main alternative to parental leave is subsidized day care. Thus, our study can be interpreted as estimating the effects of shifting time from subsidized child care to subsidized parental leave. Using data on all Swedish children born in 1988, we study how our outcome measures differ depending on the duration of parental leave entitlements, which, in turn, depend on the child's birth month. Children born in adjacent years (1987 and 1989) are used to remove the direct influences of birth months. We use compulsory school grades and national tests taken at age 16 as our primary outcomes. In addition, we study how the reform affected health, income, fertility and divorces all which are indictors of processes that have been suggested to be important in the previous literature.

The previous literature (see Boeri et al., 2005 for a thorough survey) often presumes that parents provide higher quality child care than available alternatives and that the emotional bond between a mother and a child grows stronger when the mother is at

\footnotetext{
${ }^{1}$ For example, Cunha and Heckman (2007) and Heckman (2000) claim that early interventions lead to higher overall achievement. A motivation for a recent extension of Swedish parental leave policies claimed that extended benefits allow parents to make choices that increase the welfare and development of the children (proposition 2007/08:91, page 66-67). Dustmann and Schonberg (2008) present evidence of similar motivations of German reforms.
} 
home. ${ }^{3}$ Generous parental leave benefits which increase the amount of time the parents spend with their children should therefore have positive effects on children's development. In addition, it is possible that children cared for at home benefit from extended breast feeding and are less exposed to health hazards (e.g. infections) that may be detrimental to development. ${ }^{4}$ On the other hand, maternal employment can also be positively related to child development. Employment may lead to increased family income, which may be used for alternative human capital investments, or affect the occurrence of depression among mothers. ${ }^{5}$ In addition, it is conceivable that alternative day care is of better quality than the care provided at home. Parental leave extensions may also affect fertility decisions, implying indirect effects on siblings if family size and/or child spacing affect child outcomes. ${ }^{6}$

Boeri et al. (2005) present a fairly comprehensive review of the results of earlier empirical studies regarding how mothers’ employment decisions affect early cognitive and non-cognitive skills, later educational attainment, and many other behavioral and earnings-related outcomes in adulthood. ${ }^{7}$ However, many of the reviewed studies face potentially severe problems with selection and it is therefore uncertain to what extent the estimates can be interpreted as causal.

A few recent papers have used policy reforms as natural experiments to analyze the causal long-term effects of parental leave on children's outcomes. Dustmann and Schonberg (2008) evaluate three waves of maternity leave coverage reforms in Germany in the late 1970s, 1986 and 1988. They find no evidence that the reforms

\footnotetext{
${ }^{3}$ We follow the convention in the literature to refrain from discussing the role of paternal care. Although paternal leave is a growing phenomenon in some countries, including Sweden, it was of minor importance for the cohorts studied in this paper and remains a marginal phenomenon in most countries today.

${ }^{4}$ See Berger et al (2005), Gregg et al (2005), Ruhm (2000) and Tanaka (2005).

${ }^{5}$ See Parcel and Menaghan (1994) or Moore and Driscoll (1997).

${ }^{6}$ See Lalive and Zweimüller (2008) for evidence on fertility effects of extended parental leave duration, Black et al (2005) or Åslund and Grönqvist (2007) for estimates of the effect of family size on child outcomes, and PettersonLidbom and Skogman-Thoursie (2009) for estimates of child-spacing effects on child outcomes.

${ }^{7}$ See Hill and Duncan (1987), Haveman et al (1991), Harvey (1999), Ruhm (2000), Parcel and Menaghan (1994), Han et al (2001), Baum (2002), Waldfogel et al (2002), Chase-Landsdale et al (2003), Ruhm (2004), Liu et al (2007), and Bernal (2008).
} 
improved the children's future wages or high school attendance. ${ }^{8}$ Wurtz (2007) uses a regression discontinuity approach to study a Danish prolongation of leave benefits from 14 to 20 weeks during 1984. The paper finds no significant evidence of long term effects on children's educational outcomes, as measured by high school completion and, for a small subsample, test scores. ${ }^{9}$

Our contributions are threefold. First, we use population-wide data on test scores, which enables us to measure the effects on school performance much more precisely than in previous studies. Second, our large dataset allows us to study how the effects vary with characteristics of the parents. Of particular interest is the role of mothers' education. It is well known that parents' education is one of the strongest predictors of children’s scholastic performance. Recent studies have devoted substantial effort into separating the "causal" effect of parental education from other correlated, inherited characteristics (e.g. genes). ${ }^{10}$ However, the exact mechanisms by which parents' education affects their children are still not well understood. In particular, it is possible that educated parents provide better care when at home, but equally plausible that they value, and therefore arrange for, better quality care when they are working. ${ }^{11}$ By estimating the effects of prolonged leave spells for high- and low-educated mothers separately, we are able to distinguish between these two hypotheses. Third, we provide evidence on the impact of the reform on several mechanisms suggested by the previous literature. We analyze how the reform affected child health, parent fertility and sibling spacing, as well as parental well-being, as indicated by the frequency of divorces and mothers' mental health.

Our results suggest that the duration of parental leave benefits has no effect on the school performance of the average child. Our heterogeneity analysis shows positive and statistically significant effects for children of mothers with tertiary education,

\footnotetext{
${ }^{8}$ Horisch (2008) provides a complementary analysis in the German case, adopting models of sibling differences, again finding no evidence of long run effects.

${ }_{9}^{9}$ Other credibly identified studies include Baker et al (2005) who study an extension of Quebec's kindergarten system, which could be seen as a close substitute to parental care. Using other provinces as a control group, they found that extensions of childcare which increased maternal labor supply lead to worse outcomes for the children. In addition, Baker and Milligan (2008) study an expansion of parental leave benefits in Canada from 25 weeks to 50 weeks, and find some negative effects on children's early development.

${ }^{10}$ See Björklund et al (2006) and references therein.

${ }^{11}$ As suggested by results reported in Schonkoff and Phillips (2000).
} 
suggesting that parental leave extensions strengthened the relationship between maternal education and the scholastic performance of the children. We observe no effects on mothers' future labor earnings, fertility, child health, parental separations or indicators of mothers' mental health.

The paper is structured as follows. We discuss the institutional background in Section 2. We describe the data in Section 3. Section 4 presents the empirical models. Section 5 presents the results and Section 6 concludes.

\section{Institutional background}

\subsection{Swedish parental leave policies and the 1988-89 reform $^{12}$}

The Swedish parental leave system was established in 1974. Parents were originally entitled to 6 months of paid leave at a compensation rate of 90 percent of labor earnings. The replacement rate remained at 90 percent of earnings until 1995 when it was lowered. Maximum benefits was adjusted according to inflation over the period. ${ }^{13}$ Those with no prior earnings earn a lower flat rate which remained at 60 SEK (10.1 USD in 1990) per day between 1987 and 2002. Parents are not required to use their entitled days in sequence and are allowed to use the benefits at a half or a quarter of full time. ${ }^{14}$ This flexible structure remains intact today.

As shown in Table 1, the original implementation of the policy was followed by a series of extensions between 1975 and $2002{ }^{16}$ This paper studies the reform of 1989, which provided an extension from 12 to 15 months. The reform was implemented on July $1^{\text {st }} 1989$, but retroactively covered parents of children born from October 1988

\footnotetext{
${ }^{12}$ This section draws on Sundström and Duvander (2002) and Riksförsäkringsverket (2002). Also see Björklund (2006).

${ }^{13}$ Maximum amounts are calculated as 7.5 "base amounts", where base amounts are the concept used to rescale all benefit systems in Sweden. In 1999, the cap was set at annual earnings of USD 32,300 (Sundström and Duvander, 2002). From 1995 onwards, there has been a series of reforms altering the replacement rate. Parts of the leave entitlement have been earmarked for the father (1 month from 1995 and 2 months from 2002).

${ }^{14}$ Starting 1987, parental leave days were to be used before the child turned 4 . In 1989, the rules changed back to the pre-1987 rules of usage before age 8, but evidence suggests that very few days are used after age 4 .

${ }_{16}$ Multiple births give an extra 180 days per child.
} 
onwards. In addition, parents of children born in August (September) of 1988 received 1(2) extra month(s) of leave entitlement. ${ }^{17}$

Table 1 Reforms in the parental leave benefit system

\begin{tabular}{lll}
\hline Reform year & Total number of remunerated days & $\begin{array}{l}\text { Days only compensated at the lower } \\
\text { flat rate }\end{array}$ \\
\hline 1974 & 180 & 0 \\
1975 & 210 & 0 \\
1978 & 270 & 30 \\
1980 & 360 & 90 \\
1989 & 450 & 90 \\
2002 & 480 & 90 \\
\hline
\end{tabular}

Our empirical model (see Section 4) studies children born in different months of 1988, comparing them to children born in 1987 and 1989. Given our empirical strategy, these are the most important features of the reform:

- The reform was implemented with respect to birth dates, implying that differences in entitlement between children are well-defined.

- It covered only parts of the cohort born in 1988, so we can compare outcomes within a birth cohort.

- It was launched after the births of the children born in 1988 (and before the conception of children born in 1989). Thus, the composition of children should be unaffected by the policy.

- No other relevant reforms took place during the period.

\subsection{Parental leave around the 1988-89 reform}

To assess the impact of the reform, we first use aggregate data from the National Insurance Board to calculate the number of days of paid parental leave by year, normalized by the number of children born the year before (Figure 1). The measure is somewhat crude, as parents do not always use their entitled leave in the calendar year after birth. The usage starts at the level of the old entitlement (360 days) and converges

\footnotetext{
${ }^{17}$ See the 1989:100 act on changes in the Public Insurance Act ('Lagen om allmän försäkring”) available at www.notisum.se.
} 
towards the new level of entitlement (450 days) by 1991. The pattern is entirely consistent with a report from the National Insurance Board, ${ }^{18}$ which showed that most benefit days were used during the child's first 2 years, with some non-trivial usage for an additional half year during the 1990s (see Sundström, 1996 for similar conclusions regarding the 1980s). The report also show that parents used nearly all of the benefit days they were entitled to after the extension. ${ }^{19}$ It is therefore likely that the effect was nearly complete in terms of the benefits of usage.

Additional statistics show that approximately 90 percent of days used are by parents with at least some labor earnings during the 240 days qualifying period ${ }^{20}$ and that 93 percent of parental leave days were used by mothers. Both of these numbers hold before as well as after the reform (Sundström and Duvander, 2002).

In Figure A1 in Appendix A, we use data from the Swedish Labor Force Survey to show that the total (paid or unpaid) absence "for child care reasons" of employed women with small children during the survey week increased from 20 to 25 percent around the time that the first cohorts received extended benefits. This relative increase is exactly on par with the extension of entitled benefits. The rate of absence for reasons other than child care was unchanged during the same period, for the same population.

\footnotetext{
${ }^{18}$ SOU (2005:73), page 142.

${ }^{19}$ At least 97 percent of the 360 days reimbursed at the replacement rate where actually used. In addition, between 85 and 90 percent of the 90 flat-rate days were used (numbers differ depending on birth year). Both of these statistics refer to parents to children born in the 1990s.

${ }^{20}$ Parents who give birth to a subsequent child within 24 months of an earlier childbirth can use labor earnings from the period before the earlier birth in order to qualify for benefits. These are included in the 90 percent.
} 


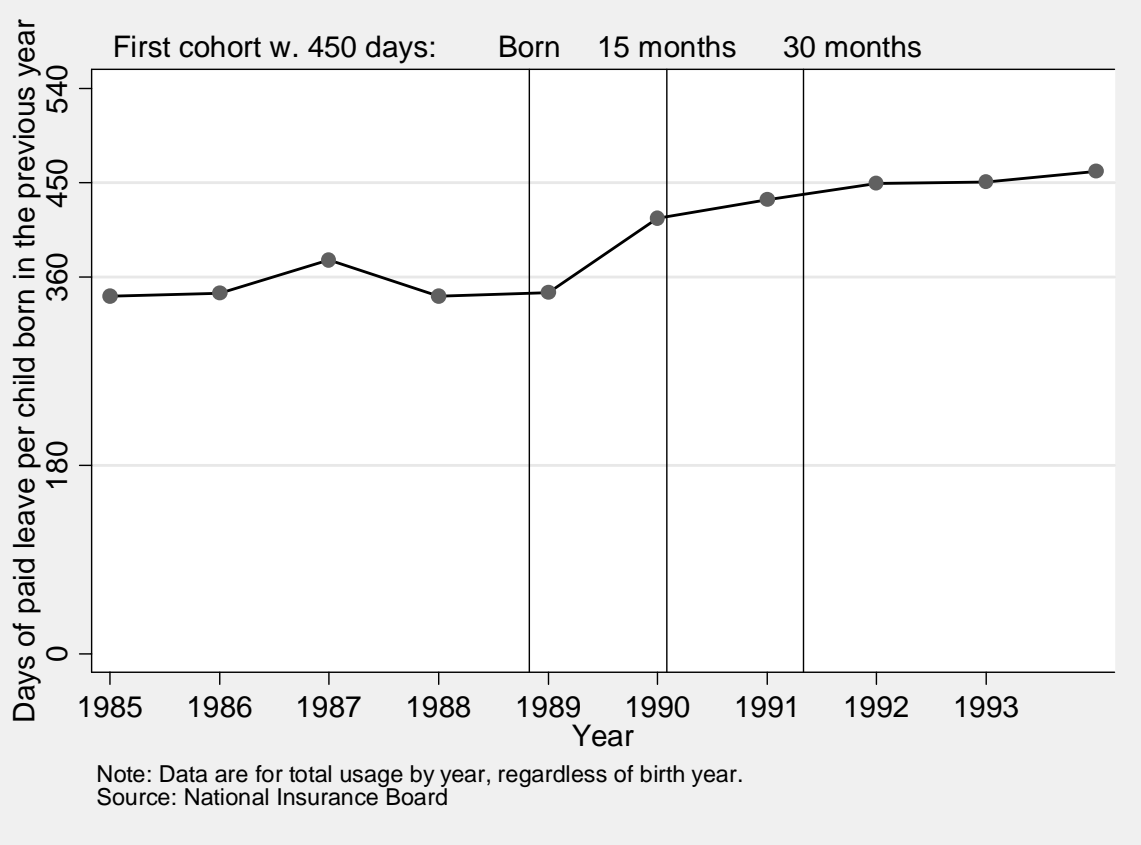

Figure 1 Full-time equivalent days of benefits per child born in the previous year

\subsection{The impact of transition rules}

Our identification relies on the transition rules applying to children born during 1988. Although the numbers presented above suggest a full long-run pass-through of the reform, they do not assess whether the impact was immediate. Figure 2 shows how real labor earnings during the calendar year after childbirth depended on the birth month for children born between 1987 and 1989. Unsurprisingly, earnings are lower the later in the year the child was born, independent of the birth year. We also see linear convergence during the transition months (August to October, 1988) when behavior smoothly adjusted from the pre-reform (1987) trajectory to the post-reform (1989) trajectory. This pattern suggests that the transition rules had real "bite" and that the impact of the reform on the mothers' behavior was immediate. Figure A2 in Appendix A shows that the pattern is equally clear independent of the mothers' education levels. Figure A3 shows a similar pattern for the second year after childbirth. 


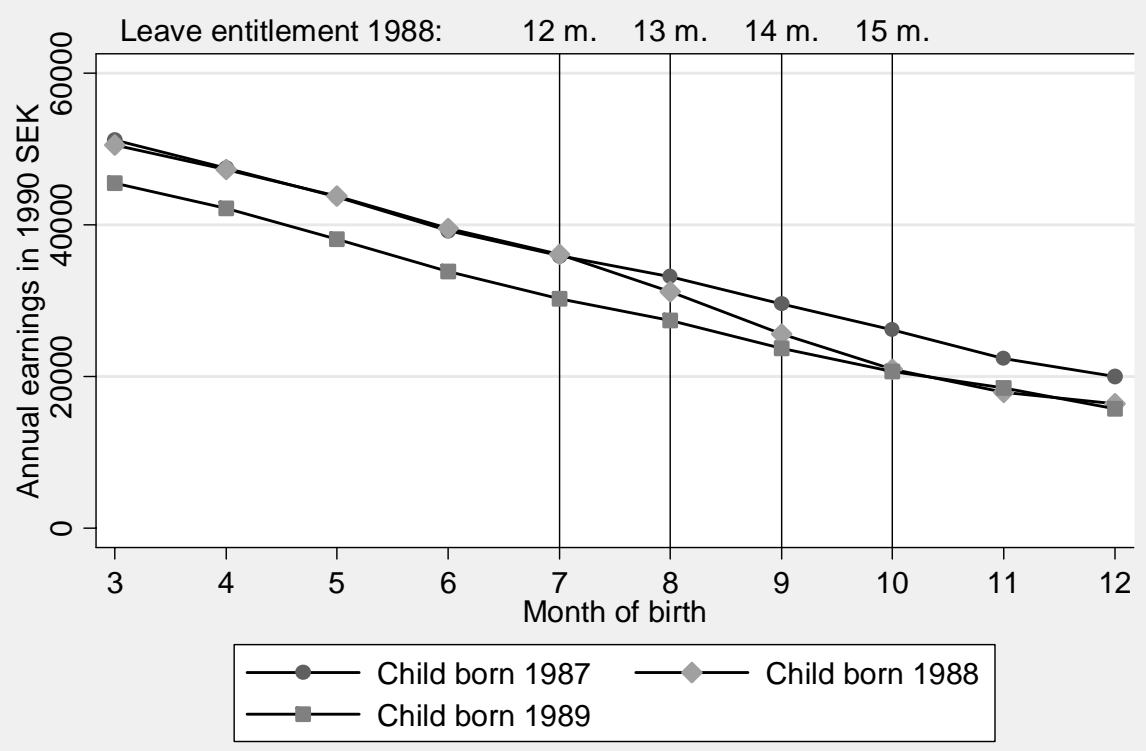

Note: Entitlement was 12 months before August 1988 and 15 months from October 1988

Earnings are during the full year after the year of child birth (i.e. during 1988, 1989 and 1990)

Figure 2 Mothers' real labor earnings during the full calendar year following the year of the child's birth - averages by month of the child's birth ${ }^{21}$

\subsubsection{The alternative: publicly provided child care}

The effects of extended parental leave policies are likely to depend on what the children would have done if their mothers had not stayed at home. In Sweden, the most frequent alternative is publicly provided, heavily subsidized, day care. Figure 3 uses survey data on the type of child care by age of the child between 1989 and $1992 .^{22}$ The figure shows that most children younger than 11 months were in parental care, both before (88 percent) and after (95 percent) the benefit extension. Among children aged 12-23 months, roughly half (40 percent before and 50 percent after) were at home with a parent.

The figure also shows that, regardless of age, very few children were catered for by alternative private child care arrangements (such as grandparents or neighbors). The vast majority of children who were not at home with their parents were either at a public day care center or at a "family center". The latter category captures day care, which is

\footnotetext{
${ }^{21}$ The average exchange rate during 1990 was 5.92 SEK/USD.

${ }^{22}$ Corresponding data were not published before 1989.
} 
financed and organized by the municipalities, although located in a care giver's home. Starting in the mid 1980s, day care centers have increasingly replaced family centers, a trend also visible in the graph. Private care has remained uncommon.

The fact that the alternative to parental care almost exclusively appears to be publicly provided child care has two main implications. First, the alternative child care is likely to be more homogenous over different types of parents as compared to situations where relatives and neighbors provide the alternative. Second, our estimates should be interpreted as the effects of shifting the policy focus from child care subsidies to parental leave benefits.

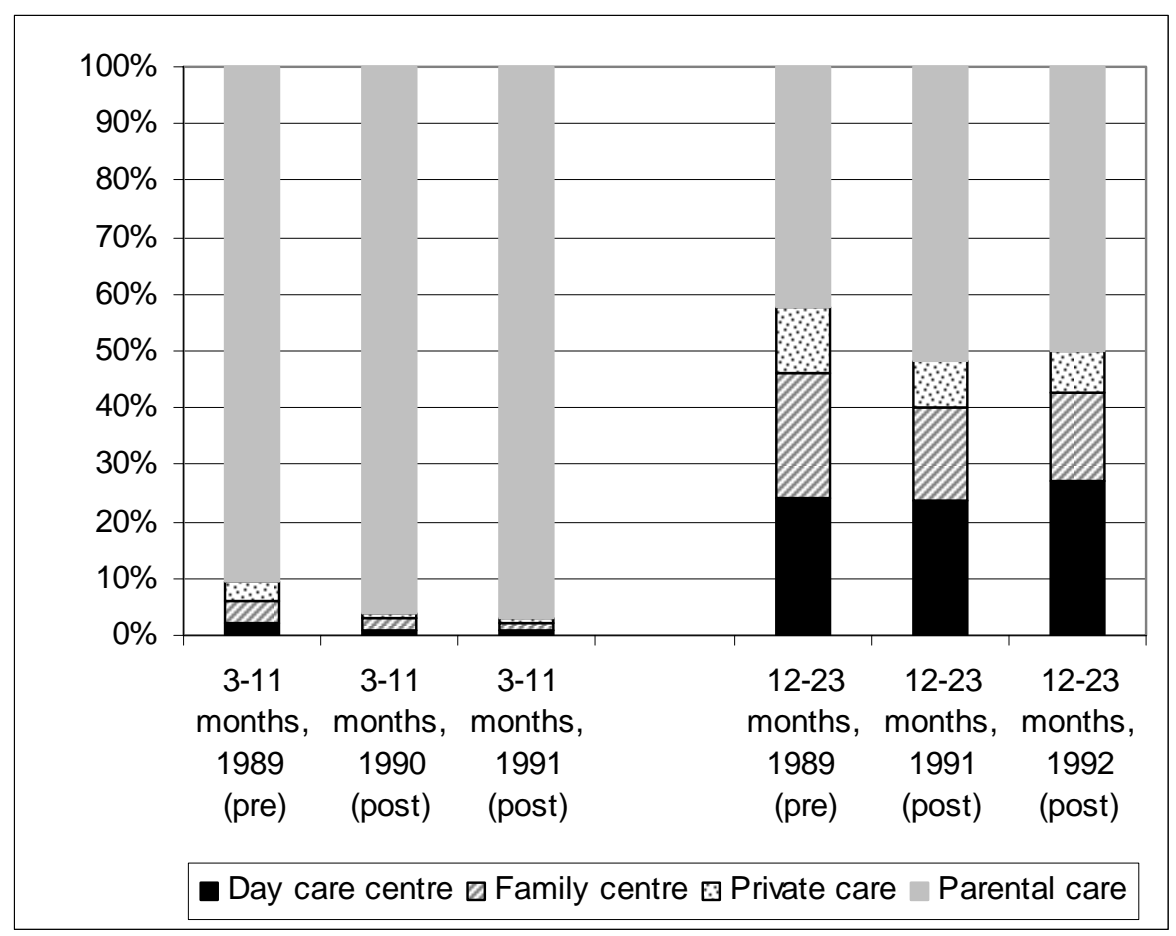

Figure 3 Care for children aged 3-11 months and 12-23 months born before (pre) and after (post) the reform

Source: Statistics Sweden’s Child Care Survey (“Barnomsorgsundersökningen”) 1989-92, Table S2.

Note: Data is for January each year. The bar for children aged 12-23 months in 1990 is not shown since some of the children are pre-reform and some are post-reform (46 percent were in parental care).

\subsubsection{Female employment and the business cycle}

During the late 1980s and the early 1990s, Sweden had a remarkably low unemployment rates and the unemployment rate for females remained between 1.5 and 3 percent between 1987 and 1991. The female employment rate of around 80 percent 
was only 4 percentage points lower than that of males. This means that the cohorts we are interested in (children born between 1987 and 1989) were born in a period where most females were employed. Furthermore, since unemployment was so low, it is reasonable to assume that the decision to work or not was a pure supply decision. ${ }^{23}$

\section{Data}

Our analysis is based on population-wide registers from the IFAU database. The database combines data from various sources, such as Statistics Sweden and the National Board of Education. Our primary sample consists of all children born in Sweden between 1987 and 1989.

We assign parental leave entitlements according to the month of birth of the child, in accordance with transition rules described in Section 2.1. These rules meant an extension of 30 days (60 days) for children born in August (September) of 1988 and 90 days thereafter. We measure the duration of parental leave entitlements in months. ${ }^{24}$

\subsection{Scholastic performance}

Our main outcomes are scholastic performance indicators at age 16. Swedish children begin school in August of their $7^{\text {th }}$ year and are mandated to participate in 9 years of schooling. Thus, compulsory schooling ends in the child's $16^{\text {th }}$ year (2003 to 2005 for the relevant cohorts). Fredriksson and Öckert (2006) present a detailed description of the Swedish institutions that are relevant when estimating the educational effects of the month of birth using Swedish data. The main complication is that some children born early in the year start (and thus complete) school one year earlier (at age 15), whereas 4 percent, most of which were born late in the year, postpone their school start. ${ }^{25}$ Grade repetition is extremely rare in Swedish schools. To reduce the impact of early school starts, we remove all children born in January or February of each year. This comes at a

\footnotetext{
${ }^{23}$ There was a substantial negative shock to the Swedish economy in the early 1990s. The unemployment rate rose rapidly to 8.2 percent for females in 1993 and employment rates plummeted, reaching 72 percent for females in 1993. But these events happened later than the relevant leave entitlement periods.

${ }^{24}$ We define a month as having 30.5 days. Thus, those born before August 1988 are assigned 11.8 months of paid leave, those born in August 1988 have 12.8 months, those born in September 1988 have 13.8 months and those born in October 1988 or after have 14.8 months of paid leave entitlement.

${ }^{25}$ Eight percent of those born in December start one year later.
} 
small cost, since the reform started in the third quarter of 1988. Since we have relatively few months after the reform, we keep children born at the end of the year. We have verified that the reform did not have any impact on delayed school starts (results are available on request).

Our main outcome is test scores from national tests administered in the final compulsory school year. These tests are intended to be used by teachers as a part of their assessment when allocating the final grades. Tests are marked locally according to a national standard and then collected by the National Board of Education. ${ }^{26}$ The national tests measure skills in mathematics, Swedish and English. These three subjects are the three core subjects in compulsory school. The math score is divided into a basic and an advanced score. Although we only report the results for the combined score, we have verified that the results are consistent over both parts. ${ }^{27}$ We transform all test results to a mean of zero and a standard deviation of 1 within each cohort (before applying any restrictions) to facilitate interpretation of the estimates and descriptive statistics. We have verified that all results hold when using outcomes scaled in terms of percentiles.

We also look at compulsory school grades, the selection tool when students apply for upper secondary education. Grades are set by the teacher in each subject using a fourtiered scale in each subject where "fail", the lowest grade, indicates inadequate performance. We use two variables based on these grades. First, the official grade point average (GPA), which is calculated by allocating 0 to each failed course and 10, 15 or 20 otherwise, depending on the grade on a maximum of 15 courses. Second, we construct a "core GPA", the average grade in the three core subjects (math, English and Swedish).

\subsection{Other outcomes}

To assess the importance of factors suggested by the previous literature, we study how the reform affected a host of intermediate processes. We analyze the timing and number

\footnotetext{
${ }^{26}$ Tests are supposedly not marked by the grading teacher, but we cannot verify that schools comply with this rule.

${ }^{27}$ We aggregate the tests by giving the advanced score the weight of 1.5 times the basic part using the same logic as when the official GPA is calculated. The tests in Swedish and in English are based on three subtests, each of which is
} 
of future siblings (on the mother's side) using mother-child links. We also use data on parental separations, where parents are considered to be separated if they are neither married nor residing at the same address at the end of the child's $14^{\text {th }}$ year. We use health data covering hospital admittances between 1987 and 2005. These data record the date of admission and the diagnosis according to the international standards ICD-9 (until 1996) or ICD-10. We construct two outcomes from these data. For children, we look at the probability of being admitted to a hospital within a number of months after birth for any reason. For mothers, we are primarily interested in the effects on mental health and therefore include all instances of admittances for mental health reasons. ${ }^{28}$ The health data are drawn from an alternative database. Thus, the samples are marginally different from the rest of the analysis, but the deviations are trivial (details are available on request). The estimated models will also have slightly different sets of control variables, as indicated below the relevant tables.

\subsection{Control variables}

Our model (see below) includes a number of control variables. The variables measure maternal and paternal employment in the November prior to childbirth, labor earnings in the year of childbirth, labor earnings prior to childbirth, the immigration status, age, county of residence at the time of child birth, dummies for the highest attained education level of the mother and father measured in the year of childbirth, the gender and birth order of the child and the number of siblings born up to 2003. In addition, we include a dummy for whether the father and mother reside in the same parish at the end of the child's birth year, serving as a proxy for being an (initially) intact family. All of these variables are drawn from population-wide registers.

graded on the four-tiered Swedish grade scale. We also aggregate these tests according to the metric used when calculating the official GPA.

${ }^{28}$ For the period up to 1996, we use ICD-9 codes in the interval 290-319, which denote "Mental disorders" (see www.ICD9Data.com). From 1997, we use ICD-10 codes in the F00-F99 interval, which denote "Mental and behavioural disorders" (see www.who.int). Differences between nomenclatures only affect a small number of cases at this level of detail. 


\subsection{Restrictions}

We place the following restrictions on our main dataset. Children in the data:

- were born in Sweden between March and December in any of the years 1987 to 1989;

- have a mother who was a Swedish resident during the year of birth and the year before that (ensuring that all are entitled to the benefits);

- $\quad$ are not twins or triplets (since special rules apply in these cases);

- participate in regular Swedish compulsory schooling at age 16 (i.e. are not enrolled in special schools for disabled children); and

- complete a national test or receive grades from compulsory school, depending on specification (i.e. non-missing outcomes).

\subsection{Data limitations}

Our data have two main limitations that are important for the setup of our study. First, we can only measure time of birth at a monthly frequency. Since the treatment intensity increases linearly with birth month between July 1988 and October 1988, we are unable to apply a meaningful regression discontinuity setup. Second, we are unable to measure the impact on parents' time off from work. Our best proxy is annual labor earnings but we are not able to use it as the first stage of an IV-model. One reason is that we cannot differentiate between potential effects on hours and effects on wages. In addition, the impact of the reform will appear during different outcome years, depending on the birth month. This creates a mechanical interaction between the reform (benefit durations) and birth month at the annual frequency. This effect is visible both in Figure 2, where the lines for 1987 and 1989 slowly converge (parents to children born in December work very little in the following year both before and after the reform), and more clearly in Figure A3, which studies the second year after birth, where the slopes are very different depending on when during a year the child is born. Although one could, in principle, look at the full impact by pooling data from a sufficient number of outcome years, this would require looking so far ahead that the estimates would be very imprecise, and 
potential wage responses are likely to bias the estimates. ${ }^{29}$ Hence, all of our estimates focus on the effect of the policy variable, i.e. leave entitlement. However, since the evidence presented in Section 2 suggests a nearly full long-run impact of the reform, the differences in interpretation should be small.

\subsection{Descriptive statistics}

Table 2 displays summary statistics, all of which show expected patterns. Approximately 40 percent of children are first-born. Half of the sample are males. The average age of mothers at childbirth is around 28 (31 for fathers). Almost 90 percent of mothers (and over 90 percent of fathers) were employed the year before their children's birth, which is consistent with the high female labor market participation rate in the late 1980s. Around three quarters of both mothers and fathers had completed at least a 2year upper secondary education and one quarter had at least some tertiary education. The descriptive statistics suggest little variation between years in the characteristics of the mothers and fathers. Most importantly for identification purposes, nothing suggests that the seasonality differs between years.

The most notable observations regarding outcomes is that those who were born in the early half of the year have, on average, much better scholastic performance, both in terms of test scores and grades. This is in line with results in Fredriksson and Öckert (2006) showing that children born early do better in school, since they are older when they start.

\footnotetext{
${ }^{29}$ Using two years after the reform (i.e. combining Figures 2 and A3), we find a total difference between post and pre-reform earnings of 9,996 SEK in real currency for children born in December. This corresponds to 16.6 percent (i.e. two months) of average annual earnings three years after childbirth for this cohort.
} 
Table 2 Summary statistics.

\begin{tabular}{|c|c|c|c|c|c|c|}
\hline & $\begin{array}{l}1987 \\
\text { March- } \\
\text { July }\end{array}$ & Aug-Dec & $\begin{array}{l}1988 \\
\text { March - } \\
\text { July }\end{array}$ & Aug-Dec & $\begin{array}{l}1989 \\
\text { March - } \\
\text { July }\end{array}$ & Aug-Dec \\
\hline GPA & 0.070 & 0.008 & 0.074 & 0.008 & 0.076 & 0.010 \\
\hline Complete & 0.916 & 0.909 & 0.917 & 0.909 & 0.913 & 0.905 \\
\hline \multicolumn{7}{|l|}{ Test results } \\
\hline Swedish & 0.066 & -0.007 & 0.038 & -0.027 & 0.040 & -0.035 \\
\hline English & 0.035 & -0.008 & 0.031 & -0.006 & 0.036 & 0.001 \\
\hline Math-Basic & 0.053 & 0.010 & 0.063 & 0.010 & 0.063 & 0.004 \\
\hline Math-Advance & 0.046 & -0.005 & 0.046 & -0.005 & 0.051 & -0.015 \\
\hline Math & 0.054 & 0.001 & 0.055 & 0.001 & 0.059 & -0.008 \\
\hline First born child & 0.407 & 0.427 & 0.406 & 0.428 & 0.414 & 0.430 \\
\hline Male child & 0.510 & 0.510 & 0.514 & 0.513 & 0.515 & 0.512 \\
\hline Intact family* & 0.950 & 0.939 & 0.947 & 0.934 & 0.943 & 0.932 \\
\hline \multicolumn{7}{|l|}{ Maternal char. } \\
\hline Age* & 28.7 & 28.4 & 28.7 & 28.4 & 28.7 & 28.3 \\
\hline $\begin{array}{r}\text { Employment** } \\
\text { Education* }\end{array}$ & 0.872 & 0.863 & 0.877 & 0.873 & 0.893 & 0.887 \\
\hline$<=9$ yrs schooling & 0.23 & 0.24 & 0.22 & 0.23 & 0.22 & 0.23 \\
\hline Upper secondary & 0.52 & 0.51 & 0.54 & 0.53 & 0.54 & 0.54 \\
\hline Tertiary & 0.25 & 0.25 & 0.25 & 0.24 & 0.24 & 0.23 \\
\hline \multicolumn{7}{|l|}{ Paternal char. } \\
\hline Age* & 31.6 & 31.3 & 31.6 & 31.3 & 31.6 & 31.2 \\
\hline $\begin{array}{r}\text { Employment** } \\
\text { Education* }\end{array}$ & 0.915 & 0.903 & 0.922 & 0.908 & 0.922 & 0.909 \\
\hline$<=9$ yrs schooling & 0.26 & 0.27 & 0.25 & 0.25 & 0.24 & 0.24 \\
\hline Upper secondary & 0.50 & 0.50 & 0.52 & 0.52 & 0.53 & 0.54 \\
\hline Tertiary & 0.24 & 0.23 & 0.23 & 0.23 & 0.23 & 0.22 \\
\hline Average month of birth & 4.95 & 9.92 & 4.93 & 9.89 & 4.96 & 9.91 \\
\hline \# Births/month & 9,320 & 7,794 & 9,855 & 8,357 & 10,057 & 8,749 \\
\hline $\mathrm{N}$ & 46,600 & 38,970 & 49,276 & 41,783 & 50,285 & 43,747 \\
\hline
\end{tabular}

Note: Child outcomes are measured at age 16. * Measured the year of childbirth. ${ }^{* *}$ Measured in November the year before childbirth. For definitions, see the text.

\section{Identification}

The parental leave reform covered parents of children born in 1988, and the coverage varied depending on when during the year the child was born. Our identification cannot rely on the variation between children born 1988 alone, since such an analysis would be confounded by generic season-of-birth effects. None of the children born in 1987, but all children born in 1989, were covered by the extension. However, since all of our 
outcomes may vary across years for other reasons (e.g. because the tests are different), we do not wish to rely on direct comparisons between birth cohorts. Furthermore, as explained in Section 3.5 we cannot use a regression discontinuity approach.

We therefore employ a model that relies on the variation in entitlement within 1988 and use data from 1987 and 1989 to purge the model of the season-of-birth effects. To this end, we first include nine seasonal birth month dummies, one for each month examined (except one), assuming that the seasonality effect is equal across years. In addition, we have a dummy for each birth cohort, which removes birth year effects that are independent of birth season. Thus, denoting the outcomes by $Y$, entitlement by $E$, dummies for season (month of birth) and year respectively by $D$ s we estimate:

$$
Y_{i}=\gamma E_{i}+D_{i}^{\text {Birth_season (month) }}+D_{i}^{\text {Year_of_birth }}+\varepsilon_{i}
$$

The parameter of interest $(\gamma)$ is properly identified if the pure effects of seasonality are the same in 1988 as in the comparison year(s). To assess the robustness of this assumption, we apply the model to three different samples: the first studying only the years 1987 and 1988; the second studying the years 1988 and 1989; and the third studying all three years.

To further strengthen the identification, we estimate a model with a linear time trend ( $T$ ) for each month (where time is measured in years). In addition, we add a set of covariates $(X)$ attempting to capture potential pre-birth differences between parents. Thus, our richest model can be written as:

$$
Y_{i}=\gamma E_{i}+D_{i}^{\text {Birth_season(month) }}+D_{i}^{\text {Birth_season(month) }} \cdot T_{i}+D_{i}^{\text {Year_of_birth }}+\beta X_{i}+\varepsilon_{i}
$$

The model described by equation (2), which is estimated based on 1987-89 data, allows for seasonal changes over time as long as the changes are linear in years. Thus, the model is identified as long as there are no month-specific events in 1988 that are unrelated to trend changes in seasonality. 
The covariates we include are measured before the relevant childbirth and capture both parents' ages (with squares), education (8 dummies), employment status in the prebirth year, labor earnings if employed (with square and cube), labor earnings in the previous year if employed (with square and cube), immigration status, a dummy for intact families and county of birth dummies. In addition, we control for the gender of the child, birth order and the number of siblings.

\subsection{Did the reform affect the composition of children?}

In Table 3, we present estimates of how the reform affected the composition of children according to a number of observable characteristics. We estimate equation (1) based on data from 1987 to 1989 using birth-order as well as parental age, employment and education as outcomes. The estimates are for one month extensions of parental leave benefits. We find no effects on the composition of children. All estimated effects of predetermined variables are miniscule and statistically insignificant. This is in line with the fact that the reform was implemented after the conception of the children. The results are reassuring since the identifying assumptions behind the empirical model in equation (1) is that there are no correlations between benefit entitlements and the innate ability of the children, conditional on year and season dummies. 
Table 3 Effects of paid parental leave entitlements on the composition of children

\begin{tabular}{|c|c|c|c|c|}
\hline Outcome & 1 & 2 & 3 & 4 \\
\hline \multirow{3}{*}{ Mother's age } & All & $\begin{array}{r}\text { Mother } \\
\text { compulsory } \\
\text { schooling }\end{array}$ & $\begin{array}{r}\text { Mother upper } \\
\text { secondary } \\
\text { schooling }\end{array}$ & $\begin{array}{r}\text { Mother at least } \\
\text { some tertiary } \\
\text { schooling }\end{array}$ \\
\hline & 0.003 & -0.017 & 0.002 & -0.015 \\
\hline & $(0.017)$ & $(0.039)$ & $(0.022)$ & $(0.030)$ \\
\hline \multirow[t]{2}{*}{ Mother employed } & 0.001 & 0.005 & -0.001 & 0.002 \\
\hline & $(0.001)$ & $(0.003)$ & $(0.001)$ & $(0.001)$ \\
\hline \multirow[t]{2}{*}{ Father's age } & 0.017 & 0.005 & 0.020 & -0.030 \\
\hline & $(0.019)$ & $(0.045)$ & $(0.026)$ & $(0.037)$ \\
\hline \multirow[t]{2}{*}{ Father employed } & -0.000 & 0.003 & -0.000 & -0.001 \\
\hline & $(0.001)$ & $(0.002)$ & $(0.001)$ & $(0.002)$ \\
\hline \multirow[t]{2}{*}{ Order of child } & -0.000 & -0.005 & 0.002 & -0.008 \\
\hline & $(0.003)$ & $(0.008)$ & $(0.004)$ & $(0.006)$ \\
\hline \multicolumn{5}{|l|}{ Mother's education } \\
\hline Compulsory education & $\begin{array}{r}-0.000 \\
(0.001)\end{array}$ & -- & -- & -- \\
\hline Tertiary & $\begin{array}{r}0.002 \\
(0.001)\end{array}$ & -- & -- & -- \\
\hline $\mathrm{N}$ & 252,393 & 57,370 & 134,106 & 60,917 \\
\hline Years & $1987-89$ & $1987-89$ & $1987-89$ & $1987-89$ \\
\hline Trend in month effects & No & No & No & No \\
\hline Covariates & No & No & No & No \\
\hline
\end{tabular}

Note: Estimates are of one month extensions of leave entitlements. All models include 9-month birth dummies and a dummy for all (but one) birth years. Robust standard errors are in parentheses. *(**, ***) Significant at the $10(5,1)$ percent level.

\section{$5 \quad$ Results}

\subsection{Main results}

Table 4 shows the estimated effects of parental leave entitlement on children's scholastic performances using data on children born in the months March to December of 1987 to 1989. The results suggest that access to longer parental leave does not have any long-term impact on the children's average scholastic performances, as measured by standardized test scores in Swedish, English, or mathematics, or as measured by overall GPA or GPA in the three core subjects. 
The results from the five different models based on equations (1) and (2) are consistent. All estimated coefficients are small and insignificant. We have verified that the results also hold if the outcomes are percentile-ranked instead of measured in terms of standard deviations. The math test has two parts: one basic and one advanced. We verified that the results hold for both parts. In addition, we have estimated the effect on the probability of a delayed school-start and the probability of getting better than a "fail" grade in all three core subjects. The results (available on request) show that these margins remain unaffected.

Table 4 The effects of paid parental leave entitlements on scholastic performance.

\begin{tabular}{|c|c|c|c|c|c|}
\hline Outcome & 1 & 2 & 3 & 4 & 5 \\
\hline $\begin{array}{l}\text { Test results } \\
\text { Swedish } \\
\text { (se) }\end{array}$ & $\begin{array}{c}0.004 \\
(0.004)\end{array}$ & $\begin{array}{c}0.004 \\
(0.004)\end{array}$ & $\begin{array}{c}0.004 \\
(0.003)\end{array}$ & $\begin{array}{c}0.004 \\
(0.003)\end{array}$ & $\begin{array}{c}0.002 \\
(0.003)\end{array}$ \\
\hline $\begin{array}{l}\text { English } \\
\text { (se) }\end{array}$ & $\begin{array}{c}0.003 \\
(0.004)\end{array}$ & $\begin{array}{l}-0.001 \\
(0.004)\end{array}$ & $\begin{array}{c}0.001 \\
(0.003)\end{array}$ & $\begin{array}{c}0.001 \\
(0.003)\end{array}$ & $\begin{array}{c}0.000 \\
(0.003)\end{array}$ \\
\hline $\begin{array}{l}\text { Math } \\
\text { (se) }\end{array}$ & $\begin{array}{c}0.001 \\
(0.004)\end{array}$ & $\begin{array}{c}0.006 \\
(0.004)\end{array}$ & $\begin{array}{c}0.004 \\
(0.003)\end{array}$ & $\begin{array}{c}0.004 \\
(0.004)\end{array}$ & $\begin{array}{c}0.002 \\
(0.003)\end{array}$ \\
\hline $\begin{array}{l}\text { Grades } \\
\text { GPA } \\
\text { (se) }\end{array}$ & $\begin{array}{c}0.000 \\
(0.004)\end{array}$ & $\begin{array}{c}0.001 \\
(0.004)\end{array}$ & $\begin{array}{c}0.001 \\
(0.003)\end{array}$ & $\begin{array}{c}0.001 \\
(0.003)\end{array}$ & $\begin{array}{c}0.001 \\
(0.003)\end{array}$ \\
\hline $\begin{array}{l}\text { GPA Core } \\
\text { (se) }\end{array}$ & $\begin{array}{c}0.002 \\
(0.004)\end{array}$ & $\begin{array}{c}0.004 \\
(0.004)\end{array}$ & $\begin{array}{c}0.003 \\
(0.003)\end{array}$ & $\begin{array}{c}0.003 \\
(0.003)\end{array}$ & $\begin{array}{c}0.003 \\
(0.003)\end{array}$ \\
\hline $\begin{array}{l}\mathrm{R} 2 \\
\mathrm{~N}\end{array}$ & $\begin{array}{c}0.00 \\
134,584- \\
163,396\end{array}$ & $\begin{array}{c}0.00 \\
158,549- \\
170,853\end{array}$ & $\begin{array}{c}0.00 \\
215,783- \\
249,731\end{array}$ & $\begin{array}{c}0.00 \\
215,783- \\
249,731\end{array}$ & $\begin{array}{c}0.16-0.21 \\
184,491- \\
212,292\end{array}$ \\
\hline $\begin{array}{l}\text { Years } \\
\text { Trend in month } \\
\text { effects } \\
\text { Covariates }\end{array}$ & $\begin{array}{c}1987-88 \\
\text { No }\end{array}$ & $\begin{array}{c}\text { 1988-89 } \\
\text { No }\end{array}$ & $\begin{array}{c}\text { 1987-89 } \\
\text { No }\end{array}$ & $\begin{array}{c}\text { 1987-89 } \\
\text { Yes }\end{array}$ & $\begin{array}{c}\text { 1987-89 } \\
\text { Yes }\end{array}$ \\
\hline \multicolumn{6}{|c|}{$\begin{array}{l}\text { Note: Estimates are of one month extensions of leave entitlements. Outcomes (except "complete grades”) } \\
\text { are standardized within birth cohort (standard deviation = 1). All models include 9-month birth dummies } \\
\text { and a dummy for all (but one) birth years. Other covariates are included in column } 5 \text {. These characterize } \\
\text { the mother and the father by age, age squared, education, county dummies (for mothers the year before } \\
\text { childbirth), employment status in the previous year, real labor earnings (with square and cube), real labor } \\
\text { earnings in the previous year (with square and cube), immigration status as well as a dummy variable for } \\
\text { intact families (at time of birth), and the child by gender, number of siblings and order of birth. The } \\
\text { number of observations differs between outcomes due to non-attendance at tests (the largest numbers } \\
\text { pertain to the grade outcomes) and between columns } 4 \text { and } 5 \text { due to missing information on background }\end{array}$} \\
\hline
\end{tabular}


characteristics (mostly missing fathers). Robust standard errors are in parentheses. *(**, ***) Significant at the $10(5,1)$ percent level.

The estimates are quite precisely equal to zero, with small standard errors. The largest estimate using the most elaborate model (column 5) is for math and Swedish (0.002). The confidence interval around this estimate only allow for effects of at most 0.8 percent of a standard deviation from a one month longer leave entitlement. For comparison, being born one month earlier would improve the test scores by an average of about 2 percent of one standard deviation. Thus, the point estimates suggest an effect on the order of being born approximately 3 days earlier. A 95 percent confidence interval allows for (at most) an effect corresponding to being born 2 weeks earlier. ${ }^{31}$

An alternative is to compare the results to the educational differences depending on the mothers' education levels. Cross-sectional estimates (results available upon request) show that children of mothers with a 3-year upper secondary diploma have 30 percent of one standard deviation better results than children of mothers with a 2-year (vocational) diploma. These estimates cannot be interpreted causally, but provide an interesting baseline. An extra month of leave entitlement is on the order of 3 days of maternal education. The confidence interval allows one month extra leave to affect the test scores by the same amount as 1.2 weeks of maternal education. ${ }^{32}$

\subsection{The role of mothers' education}

In this subsection, we estimate the effects of prolonged parental leave durations for well-educated and low-educated mothers. Since the extension of parental leave entitlements shifts time from public child care to maternal care, we are able to see whether high- (or low-) educated mothers provide more human capital accumulation at home relative to the public day care system. By doing so, we are able to provide evidence on why children of highly educated parents perform better in school.

Table 5 shows the results for the sample divided into three education groups: only compulsory school, upper secondary, and at least some tertiary. The first and last groups each include approximately one quarter of the sample. The results show that the

\footnotetext{
${ }^{31}$ Each day increases test scores by $0.02 /(30.5)$. For the point estimates, 3 days*0.02/30.5 $=0.002$. The upper bound for the confidence interval is $0.002+2 * 0.003=0.008$ and 12 days $* 0.02 / 30.5 \approx 0.008$.

${ }_{32}$ Assuming that one year in upper secondary education corresponds to 45 weeks of education, each week improves the test scores by $0.3 / 45=0.0067$ and $1.2 * 0.0067 \approx 0.008$.
} 
duration of parental leave has a positive and statistically significant effect on children of well-educated mothers. One month of additional parental leave entitlement improves the test results by 2 percent of one standard deviation for these children. This is on the order of being born almost one month earlier. On the other side of the scale, all coefficients are negative but insignificant for the quarter of children whose mothers only attended compulsory school. We have verified that these results hold in all models shown in Table 3 and also when looking at percentile-ranked test scores. ${ }^{33}$ In the second part of Table 5, we show estimates from samples split according to fathers' education, but all estimates are small and insignificant.

One possible concern is that poorly-educated mothers may have been less informed about the transition rules. However, in Figure A1 in Appendix A, we display the real annual earnings impact of the reform for both the most- and least-educated mothers during the year after each cohort was born, depending on birth month. ${ }^{34}$ As shown in the figure, the transition rules seem to have had a full impact on both the least- and mosteducated groups. In both cases, the behavior of the mothers of children born in 1988 fully converges from the pre-reform to the post-reform behavior during the transition months. We have also verified that the result holds if we remove the two months (August and September) that were only partially covered by the extension. ${ }^{35}$ Thus, the differences in outcomes between the education groups do not seem to be the result of differences in information regarding rights to benefits during the transition months.

\footnotetext{
${ }^{33}$ An estimate of 0.02 standard deviations corresponds to approximately half a percentile rank.

${ }^{34}$ For the impact on the whole sample, see Figure 3.

${ }^{35}$ In addition, we removed December, where delayed school starts are more frequent, again finding very similar results.
} 
Table 5 Heterogeneity: Mothers' and fathers' education levels

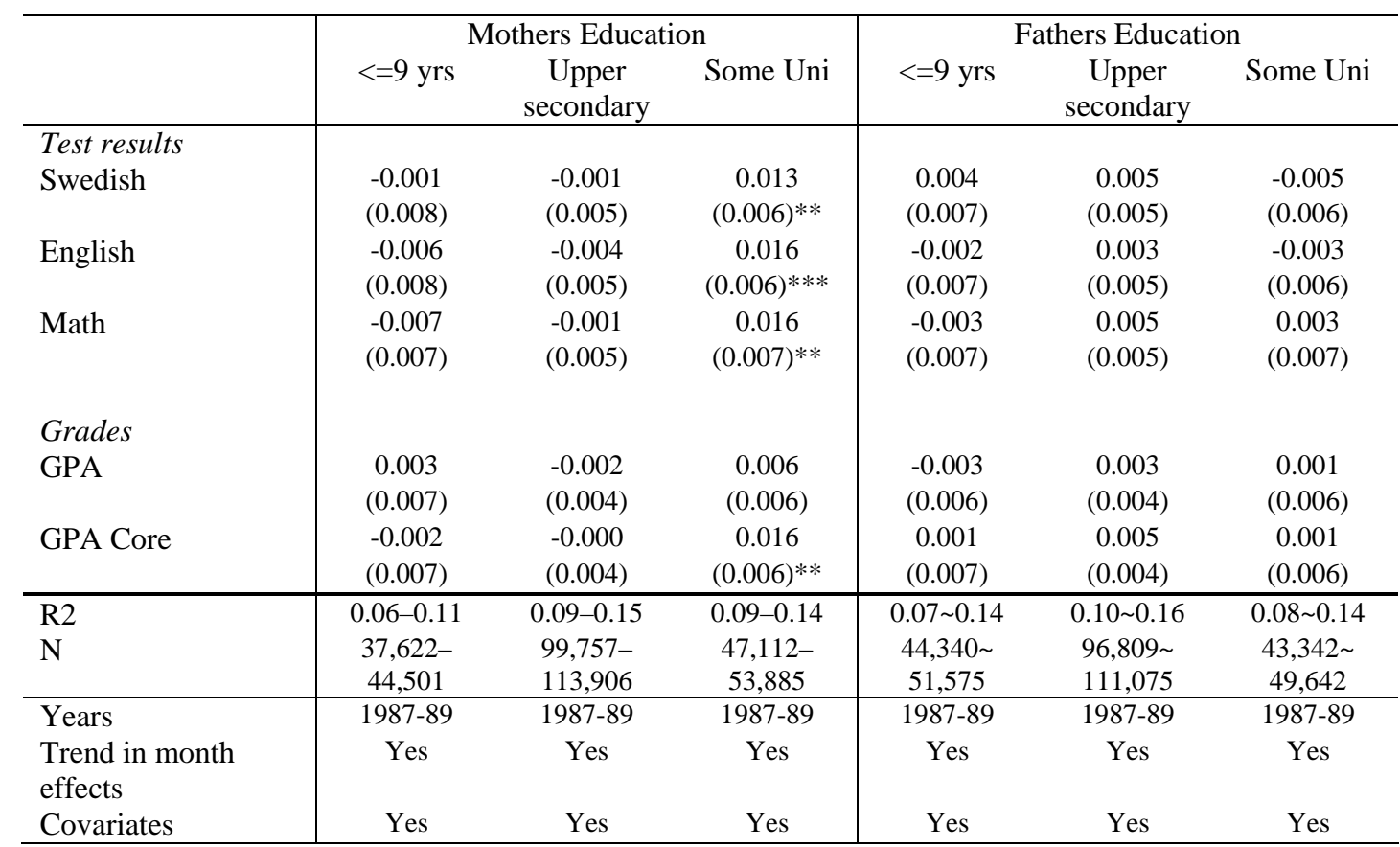

Note: Estimates are of one month extension of leave entitlements. The models are identical to the last column of Table 3, including covariates. The number of observations differs between outcomes due to nonattendance at tests (the largest numbers pertain to the grade outcomes). Robust standard errors are in parentheses. $*(* *, * * *)$ Significant at the $10(5,1)$ percent level.

One possible interpretation of the estimates is that maternal education serves as a proxy for mothers' earnings, which in turn determine benefit levels. Since benefit levels are determined by earnings in the last 240 days before childbirth, we have analyzed how the outcomes vary with mothers' annual earnings in the pre-birth year. The estimates presented in Table 6 do not support the notion that the effects are larger for mothers with high pre-birth labor earnings (and therefore greater benefits). We find similar results when splitting the sample according to the fathers', or both parents', earnings percentiles or when using residual earnings (results available on request). 
Table 6 Heterogeneity: Mothers' earnings and children's predicted grades

\begin{tabular}{|c|c|c|c|c|c|c|}
\hline & \multicolumn{3}{|c|}{ Mothers Earnings Percentiles } & \multicolumn{3}{|c|}{ Predicted GPA } \\
\hline & $<25 \%$ & {$[25 \%-75 \%]$} & $>75 \%$ & $<25 \%$ & {$[25 \%-75 \%]$} & $>75 \%$ \\
\hline \multicolumn{7}{|l|}{ Test results } \\
\hline \multirow[t]{2}{*}{ Swedish } & -0.007 & 0.004 & 0.008 & 0.005 & -0.000 & 0.006 \\
\hline & $(0.007)$ & $(0.005)$ & $(0.006)$ & $(0.007)$ & $(0.005)$ & $(0.006)$ \\
\hline \multirow[t]{2}{*}{ English } & -0.005 & 0.001 & 0.004 & 0.005 & -0.001 & 0.004 \\
\hline & $(0.007)$ & $(0.005)$ & $(0.006)$ & $(0.007)$ & $(0.005)$ & $(0.006)$ \\
\hline \multirow[t]{2}{*}{ Math } & -0.004 & 0.006 & 0.003 & -0.003 & 0.006 & 0.004 \\
\hline & $(0.007)$ & $(0.005)$ & $(0.007)$ & $(0.007)$ & $(0.005)$ & $(0.007)$ \\
\hline \multicolumn{7}{|l|}{ Grades } \\
\hline \multirow[t]{2}{*}{ GPA } & -0.001 & 0.002 & 0.002 & 0.002 & 0.001 & 0.000 \\
\hline & $(0.007)$ & $(0.004)$ & $(0.005)$ & $(0.007)$ & $(0.004)$ & $(0.006)$ \\
\hline \multirow[t]{2}{*}{ GPA Core } & -0.003 & 0.005 & 0.006 & 0.001 & 0.005 & 0.003 \\
\hline & $(0.007)$ & $(0.004)$ & $(0.006)$ & $(0.007)$ & $(0.004)$ & $(0.006)$ \\
\hline $\mathrm{R} 2$ & $0.15-0.20$ & $0.12-0.18$ & $0.14-0.21$ & $0.04-0.06$ & $0.07-0.08$ & $0.08-0.10$ \\
\hline \multirow[t]{2}{*}{$\mathrm{N}$} & $39,682-$ & $94,754-$ & $50,055-$ & 41,952- & 94,303- & 48,087- \\
\hline & 46,260 & 108,735 & 57,297 & 49,435 & 107,775 & 55,082 \\
\hline Years & 1987-89 & 1987-89 & $1987-89$ & 1987-89 & $1987-89$ & $1987-89$ \\
\hline $\begin{array}{l}\text { Trend in month } \\
\text { effects }\end{array}$ & Yes & Yes & Yes & Yes & Yes & Yes \\
\hline Covariates & Yes & Yes & Yes & Yes & Yes & Yes \\
\hline
\end{tabular}

Note: Estimates are of one month extensions of leave entitlements. Earnings percentiles are calculated for all mothers using data for the year before birth. The number of observations differs between lowest and highest quartile due to differences in the number of missing values on the outcomes. The GPA predictions are based on a regression using 1987 data. All covariates described below Table 3 (except mothers' education) are included in the prediction. The models are identical to the last column of Table 3. The number of observations differs between outcomes due to non-attendance at tests (the largest numbers pertain to the grade outcomes). Robust standard errors are in parentheses. $*(* *, * *)$ Significant at the $10(5,1)$ percent level.

An alternative explanation is that the pattern we find is due to the quality of the children. As noted, children of highly educated mothers are better students, on average, and it is possible that the effects of parental time differ depending on the general ability of the students. The absence of heterogeneity with respect to fathers' education speaks against this explanation in part but to further test the hypothesis, we split the sample based on predicted school performance using all available characteristics except mothers' education. The estimates for different samples of predicted performance shown in the second part of Table 6 are all insignificant and small, suggesting that the positive effects for children with highly educated mothers is not driven by the overall quality of the children. ${ }^{36}$

\footnotetext{
${ }^{36}$ If we include mothers' education in the prediction, we find some positive estimates. However, they are smaller than if we only split the sample according to the mothers' education.
} 


\subsubsection{Heterogeneity in other dimensions}

We investigated a number of other dimensions, but found no evidence of heterogeneity with respect to mothers' or fathers' immigration statuses, pre-birth employment statuses, whether the family is intact at the end of the birth year, the gender of the child, or whether the child is born first or last in the family. The only exception is for the small sample of lone children, where we find significant positive results. However, this result is not entirely robust, and we do not have any straightforward explanation for it. ${ }^{37}$

\subsection{Mechanisms}

Here we provide evidence related to mechanisms suggested by the earlier literature, such as future labor earnings, child health, fertility and parental well-being. We do this for the full sample as well as for the lowest and highest educated groups.

We start by looking at the long-run effects on mothers' earnings. The results are shown in Table 7. We use real annual earnings and find no evidence of long-run effects on the labor market outcomes of mothers, which is consistent with the results of Lalive and Zweimuller (2008). Figure 4 shows the impact on earnings 6 years after childbirth for the groups with most and least education. Unfortunately, due to a lack of data, we are unable to estimate the effects on working hours and wages.

\footnotetext{
${ }^{37}$ A possible interpretation is that these children are more constrained in terms of maternal time, since they cannot "free ride" on parental leave conferred for siblings. Note though that this interpretation is inconsistent with the perceived negative effects of family size (Black et al., 2005). Note also that the estimates are insignificant in models that do not include covariates and they do not stand for the type of test we present for mothers' education in Section 5.4 below.

${ }^{39}$ See www.unicef.org.
} 


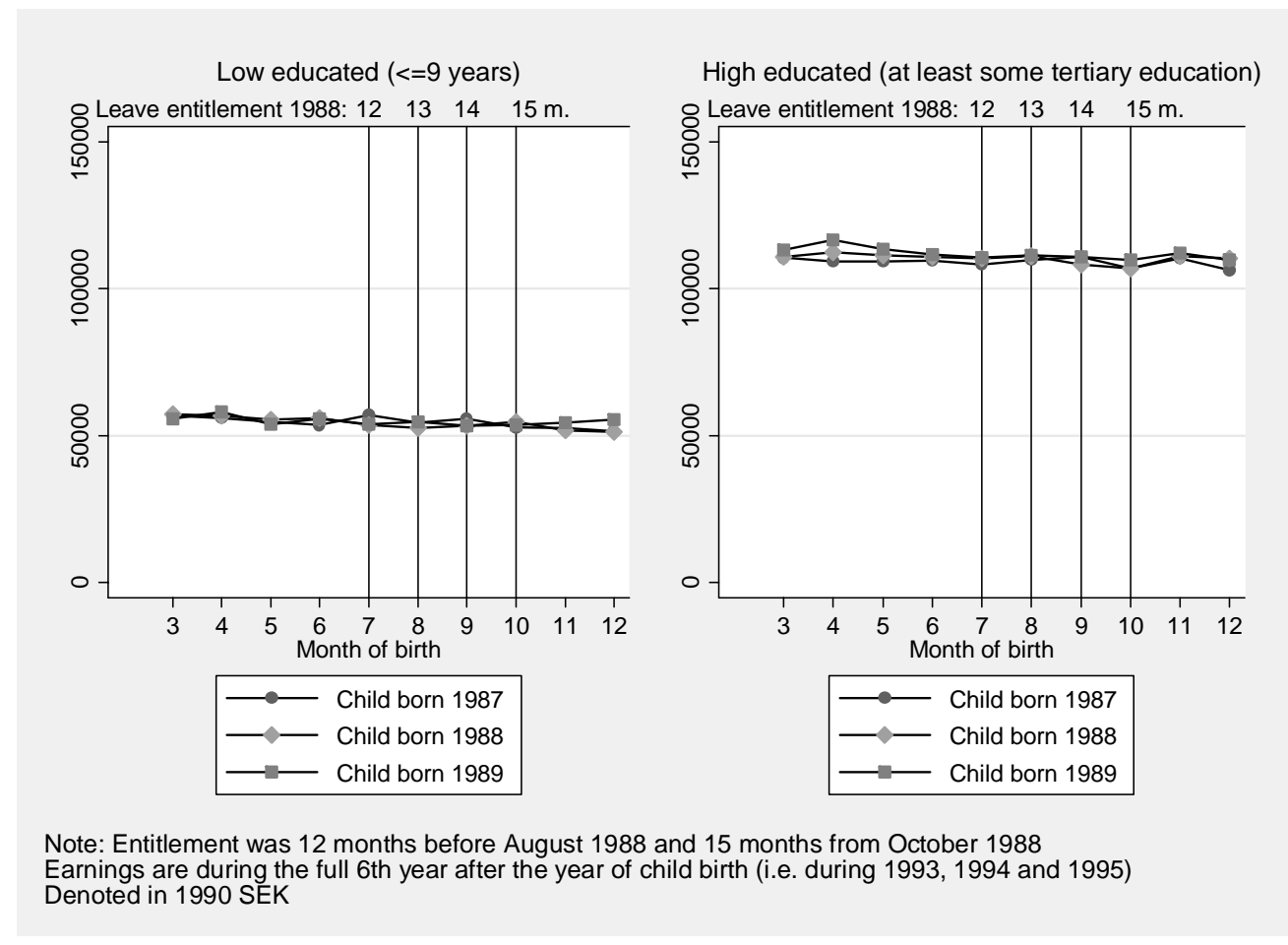

Figure 4 Birth month and mothers' real annual earnings 6 years later; averages by birth month

The second panel of Table 7 looks at indicators of children's health. We use data on admittances to hospitals to estimate how the leave extensions affected the probability of being admitted to a hospital at least once within 3, 6 and 16 years after birth. We find no evidence of health effects of increased parental leave at any of these durations, or for any of the subgroups. 
Table 7 Effects on earnings, fertility, parental well-being and health

\begin{tabular}{|c|c|c|c|c|}
\hline & & \multicolumn{3}{|c|}{ Estimated effects of entitlement } \\
\hline $\begin{array}{l}\text { Dependent } \\
\text { variable }\end{array}$ & $\begin{array}{c}\text { Mean of dependent } \\
\text { variable: } \\
\text { All [low ed./high ed.] }\end{array}$ & All & $\begin{array}{l}\text { Low educated } \\
\text { (<=9 years) }\end{array}$ & $\begin{array}{l}\text { High educated } \\
\text { (Tertiary) }\end{array}$ \\
\hline \multicolumn{5}{|c|}{ 1, Mothers labor earnings (100s of 1990s SEK) } \\
\hline After 3 years & $\begin{array}{c}639 \\
{[500 / 894]}\end{array}$ & $\begin{array}{c}0.578 \\
(1.567)\end{array}$ & $\begin{array}{c}0.735 \\
(2.970)\end{array}$ & $\begin{array}{c}2.913 \\
(3.664)\end{array}$ \\
\hline After 7 years & $\begin{array}{c}819 \\
{[585 / 1190]}\end{array}$ & $\begin{array}{c}0.703 \\
(1.787)\end{array}$ & $\begin{array}{c}0.820 \\
(3.541)\end{array}$ & $\begin{array}{c}4.219 \\
(4.053)\end{array}$ \\
\hline \multicolumn{5}{|c|}{ 2, Child admitted to hospital (any reason) } \\
\hline Within 3 years & $\begin{array}{c}0.330 \\
{[0.365 / 0.302]}\end{array}$ & $\begin{array}{c}0.000 \\
(0.002)\end{array}$ & $\begin{array}{l}-0.004 \\
(0.003)\end{array}$ & $\begin{array}{c}0.004 \\
(0.003)\end{array}$ \\
\hline Within 6 years & $\begin{array}{c}0.384 \\
{[0.416 / 0.354]}\end{array}$ & $\begin{array}{c}0.000 \\
(0.002)\end{array}$ & $\begin{array}{l}-0.002 \\
(0.003)\end{array}$ & $\begin{array}{c}0.001 \\
(0.003)\end{array}$ \\
\hline Within 16 years & $\begin{array}{c}0.539 \\
{[0.575 / 0.505]}\end{array}$ & $\begin{array}{l}-0.000 \\
(0.002)\end{array}$ & $\begin{array}{l}-0.001 \\
(0.004)\end{array}$ & $\begin{array}{l}-0.000 \\
(0.003)\end{array}$ \\
\hline \multicolumn{5}{|l|}{ 3, Younger siblings } \\
\hline Within 18 months & $\begin{array}{c}0.058 \\
{[0.067 / 0.045]}\end{array}$ & $\begin{array}{l}0.002^{* *} \\
(0.001)\end{array}$ & $\begin{array}{c}0.002 \\
(0.002)\end{array}$ & $\begin{array}{l}0.003^{*} \\
(0.001)\end{array}$ \\
\hline Within 24 months & $\begin{array}{c}0.163 \\
{[0.161 / 0.155]}\end{array}$ & $\begin{array}{c}0.002 \\
(0.001)\end{array}$ & $\begin{array}{c}0.000 \\
(0.003)\end{array}$ & $\begin{array}{c}0.001 \\
(0.003)\end{array}$ \\
\hline Within 3 years & $\begin{array}{c}0.337 \\
{[0.309 / 0.337]}\end{array}$ & $\begin{array}{c}0.001 \\
(0.002)\end{array}$ & $\begin{array}{l}-0.004 \\
(0.003)\end{array}$ & $\begin{array}{c}0.001 \\
(0.003)\end{array}$ \\
\hline Within 6 years & $\begin{array}{c}0.512 \\
{[0.491 / 0.493]}\end{array}$ & $\begin{array}{c}0.001 \\
(0.002)\end{array}$ & $\begin{array}{c}0.001 \\
(0.003)\end{array}$ & $\begin{array}{c}0.000 \\
(0.003)\end{array}$ \\
\hline Within 16 years & $\begin{array}{c}0.577 \\
{[0.577 / 0.528]}\end{array}$ & $\begin{array}{l}-0.000 \\
(0.001)\end{array}$ & $\begin{array}{l}-0.002 \\
(0.003)\end{array}$ & $\begin{array}{c}0.000 \\
(0.003)\end{array}$ \\
\hline Total number & $\begin{array}{c}1.767 \\
{[2.001 / 1.633]}\end{array}$ & $\begin{array}{c}0.001 \\
(0.003) \\
\end{array}$ & $\begin{array}{c}0.002 \\
(0.007) \\
\end{array}$ & $\begin{array}{l}-0.002 \\
(0.005) \\
\end{array}$ \\
\hline \multicolumn{5}{|l|}{ 4, Parents separated } \\
\hline At age 14 & $\begin{array}{c}0.357 \\
{[0.485 / 0.232]} \\
\end{array}$ & $\begin{array}{c}0.001 \\
(0.002) \\
\end{array}$ & $\begin{array}{l}-0.002 \\
(0.004)\end{array}$ & $\begin{array}{c}0.003 \\
(0.003)\end{array}$ \\
\hline \multicolumn{5}{|c|}{ 5, Mother admitted to hospital for mental health disorders } \\
\hline Within 3 years & $\begin{array}{c}0.008 \\
{[0.015 / 0.004]}\end{array}$ & $\begin{array}{l}-0.000 \\
(0.000)\end{array}$ & $\begin{array}{l}-0.000 \\
(0.001)\end{array}$ & $\begin{array}{c}0.000 \\
(0.000)\end{array}$ \\
\hline Within 6 years & $\begin{array}{c}0.013 \\
{[0.024 / 0.007]}\end{array}$ & $\begin{array}{c}0.000 \\
(0.000)\end{array}$ & $\begin{array}{c}0.001 \\
(0.001)\end{array}$ & $\begin{array}{c}0.001 \\
(0.001)\end{array}$ \\
\hline Within 16 years & $\begin{array}{c}0.038 \\
{[0.069 / 0.022]}\end{array}$ & $\begin{array}{l}-0.000 \\
(0.001)\end{array}$ & $\begin{array}{c}0.000 \\
(0.002)\end{array}$ & $\begin{array}{c}0.001 \\
(0.001)\end{array}$ \\
\hline $\mathrm{N}$ & & $\begin{array}{c}227,697- \\
264,940\end{array}$ & $\begin{array}{c}49,105- \\
53,789\end{array}$ & $\begin{array}{c}57,257- \\
68,150\end{array}$ \\
\hline Years & & $1987-89$ & $1987-89$ & $1987-89$ \\
\hline $\begin{array}{l}\text { Trend in month } \\
\text { effects }\end{array}$ & & Yes & Yes & Yes \\
\hline Covariates & & Yes $^{\mathrm{A}}$ & Yes $^{\mathrm{A}}$ & Yes $^{\mathrm{A}}$ \\
\hline
\end{tabular}


The third panel looks at fertility and child "spacing” (the distance between siblings) to see whether the extended leave spells affected the competition for time within the family. Note that the analysis is partial in the sense that we estimate the fertility effect of having a longer leave period for the previous child and not the, potentially large, anticipatory effects of more generous fertility benefits (see Björklund, 2006, for an analysis of the overall effects of Swedish parental leave benefits on fertility). The only significant effect we find is a small (0.2 percentage points) increase in the probability of having an additional child very soon (within 18 months of the last), which appears to be driven by highly educated mothers. The effect vanishes if we include births up to 24 months. This effect is interesting, since it suggest that parents may reduce the space between their children if spells of parental leave become sufficiently long to facilitate sequential births without intermediate return to work. However, the effects are unlikely to contribute to our results regarding cognitive skills. The effects are too small and if anything should exert a negative effect on the children to well-educated mothers if we trust the evidence in the existing literature (see Petterson-Lidbom and SkogmanThoursie, 2009).

Finally, we look at indicators of general parental well-being. As proxies, we use the probability that parents separate and whether the mother is admitted to a hospital due to a mental disorder. We find no evidence suggesting that parental leave benefits have any effects on these outcomes either, irrespective of education levels. We also verified that the reform had no effects the overall rate of hospital admittances, irrespective of diagnosis. Admittedly, our measures are rather crude and may be only loosely related to general well-being. However, taken at face value, the estimates provide no indication that parental well-being, as measured by these variables, is affected by the duration of parental leave for any of the education groups.

\subsection{Robustness: benefit extensions and the relative performance of children of educated mothers}

Having analyzed a number of subsamples and outcomes, one possible concern is that the significant effects found for highly educated mothers may be spurious. Although the link is plausible for theoretical reasons, we would still like to corroborate our results using some alternative identifying variation. Therefore, we estimate a difference-in- 
difference (DD) model describing how parental leave entitlement affects children of highly educated mothers relative to children of low educated mothers. We exclude all observations from 1988 so as to purge the analysis of the within-year variation we have relied on so far. Instead, we only use data from the last complete pre-reform year (1987) and the first complete post-reform year (1989). Formally, we employ the following model:

$$
Y_{i}=\lambda E_{i} * D_{i}^{\text {High_Educated }}+D_{i}^{\text {High } \text { Educated }_{2}}+\varphi E_{i}+\beta X_{i}+\varepsilon_{i}
$$

where the notation is as before. Since entitlement does not vary within a year in this model, the entitlement variable captures common (i.e. education invariant) differences between years. We only include children of mothers with either less than upper secondary education or at least some tertiary education. Estimates of $\lambda$ show how the benefits extensions changed the association between mothers' education and children's cognitive skills.

The results in the first column of Table 8 show positive and significant estimates of most outcomes, suggesting that the benefits extension improved the relative performance of children to well-educated mothers. We do not have test score data on cohorts born before 1987. However, assuming that the reform only affected the level of relative performance and not the trend, we can purge the analysis of the influence of trends by using an additional post-reform year (i.e. children born 1990). This model includes year dummies as well as an interaction term between time (linear in years) and maternal education. The results, shown in the second column of Table 8, become less precise in this specification, but the point estimates are almost unaffected. Overall, the results in Table 5 and Table 8 consistently suggest that longer parental leave spells improve the relative performance of children to highly educated mothers. 
Table 8 D-D estimates of the effects of paid parental leave entitlements on the relative performance of children to highly educated mothers

\begin{tabular}{|c|c|c|}
\hline & $(1)$ & $(2)$ \\
\hline \multicolumn{3}{|l|}{ Test results } \\
\hline Swedish & $\begin{array}{c}0.012 \\
(0.005)^{* *}\end{array}$ & $\begin{array}{c}0.015 \\
(0.013)\end{array}$ \\
\hline English & $\begin{array}{c}0.003 \\
(0.005)\end{array}$ & $\begin{array}{c}0.012 \\
(0.013)\end{array}$ \\
\hline Math & $\begin{array}{c}0.055 \\
(0.005)^{* * *}\end{array}$ & $\begin{array}{c}0.072 \\
(0.013)^{* * *}\end{array}$ \\
\hline \multicolumn{3}{|l|}{ Grades } \\
\hline GPA & $\begin{array}{c}0.009 \\
(0.005)^{* *}\end{array}$ & $\begin{array}{c}0.017 \\
(0.012)\end{array}$ \\
\hline GPA Core & $\begin{array}{c}0.010 \\
(0.005)^{* *}\end{array}$ & $\begin{array}{c}0.015 \\
(0.013)\end{array}$ \\
\hline $\mathrm{R} 2$ & $0.07-0.27$ & $0.07-0.27$ \\
\hline $\mathrm{N}$ & $54373-65298$ & 85537-96509 \\
\hline Years & 1987,1989 & 1987, 1989-90 \\
\hline $\begin{array}{l}\text { Interaction of highly-educated } \\
\text { mothers and linear trend (year) }\end{array}$ & No & Yes \\
\hline Covariates & Yes & Yes \\
\hline
\end{tabular}

\section{Discussion}

Article 3 of the UN Convention on the Rights of the Child requires that the best interest of a child is the primary consideration when policies that affect children are designed. The Convention is legally binding for ratifying countries which include most UN member states (except the US). ${ }^{39}$ Taken seriously, this convention suggests a need for credible evidence about the causal effects of family policies on child outcomes. This paper aims to provide such evidence by analyzing how extensions of paid parental leave periods affect children's futures. We use a quasi-experimental strategy to isolate the effects of parental benefits on children's scholastic performance. Our results suggest that the average performance of the children was unaffected by parental leave durations. This is in accordance with two recent studies using similar strategies on Danish (Wurtz, 
2007) and German (Dustmann and Schonberg, 2008) data to identify the long-term effects of parental leave policies on children, although on slightly different outcomes. ${ }^{40}$

Using population-wide data allows us to further identify the effects for different parts of the population. We do find significant positive effects for children of well-educated mothers and negative, but insignificant, results for children of poorly educated parents.

We also study a number of intermediate outcomes related to processes discussed in the existing literature. We study long-run earnings effects for mothers, and effects on child health, fertility decisions, parental separations and indicators of the mothers' mental health. None of these outcomes appear to have been affected by the reform for any of the education groups, with the exception of a small reduction in subsequent child spacing among well-educated mothers.

Given that: i) we do not find an impact on intermediate outcomes; ii) we fail to find heterogeneity with respect to fathers' education, parents' pre-birth earnings or other indicators of children's scholastic quality; and iii) the difference in impact is corroborated by a between-cohort comparison of the relative performance of children with mothers of different education; we interpret the estimates as suggesting that there are positive interaction-effects between time spent at home and maternal education. The results are consistent with an interpretation in which the Swedish public child care system provides less human capital accumulation than well-educated mothers, but (at least) as much as low educated mothers.

From a policy perspective, our results suggest that expanding parental leave entitlements does not improve schooling results on average, nor does it appear to have any beneficial distributional effects or any beneficial effects on child health. Thus, our results suggest that extensions of parental leave policies, at least in countries that already have quite generous benefits and extensive child care subsidies, cannot be motivated by improved outcomes among children.

\footnotetext{
${ }^{40}$ Ongoing work by Carniero et al. (2009) find very large positive effects of a Norwegian leave extension in the mid 1970s. The results suggest that high school drop-out rates were reduced by 3 percentage points (and height at age 18 reduced by nearly a centimeter) due to an extension of parental leave from 4 to 6 months. One possible explanation for why these results deviate from the rest of the emerging literature is that the paper studies shorter leave periods. The authors interpret the results as being driven by an increased frequency of breast feeding which is unlikely to be an important factor at the margin we are studying in this paper.
} 


\section{References}

Åslund O. and H. Grönqvist (2007) "Family size and child outcomes: Is there really no trade off?", IFAU Working paper 2007:15

Baker M., J. Gruber and K. Milligan (2005) "Universal Childcare, Maternal Labor supply, and Family Well-Being”, NBER Working Paper No. 11832

Baker M., and K. Milligan (2008) "Evidence from Maternity Leave Expansions on the Impact of Maternal Care on Early Child Development”, Journal of Political Economy, Vol. 116, No. 4.

Baum II, C. L. (2003) “Does Early Maternal Employment Harm Child Development? An Analysis of the Potential Benefits of Leave Taking”, Journal of Labor Economics, 27-2, 408-448

Bernal R. (2008) “The Effect of Maternal Employment and Child Care on Children s Cognitive Development”, International Economic Review, vol 49(4), 1173-1209.

Berger L. M., J. Hill and J. Waldfogel (2005) Maternity Leave, Early Maternal Employment and Child Health and Development in the US, Economic Journal, 115 (February), F29-F47.

Björklund A. (2006) "Does Family Policy Affect Fertility? Lessons from Sweden” Journal of Population Economics 19, 3-24.

Björklund A., M. Lindahl and E. Plug (2006) The Origins of Intergenerational Associations: Lessons from Swedish Adoption Data” Quarterly Journal of Economics, August, 999-1028.

Black S., P. Devereaux and K. Salvanaes (2005) "The More the Merrier? The Effects of Family Composition and Children’s Education”, Quarterly Journal of Economics, vol 120, 669-700.

Boeri T., D. D. Boca, and C. Pissarides (2005) Women at Work: An Economic Perspective, Oxford University Press, Oxford. 
Carneiro P. and J. Heckman (2003) Human Capital Policy, in Inequality in America: What Role for Human Capital Policies? MIT Press, Cambridge.

Carneiro P., K. Loken and K. Salvanaes (2009) “A Flying Start? Maternity leave and long run outcomes for mother and child “, Mimeo (February 2009) Norwegian school of Economics and Business Administration, Bergen.

Chase-Lansdale L. P., R. A. Moffitt, B. J. Lohman, A. J. Cherlin, R. L. Coley, L. D. Pittman, , J. Roff and E. Votruba-Drzal (2003) “Mother’s Transition from Welfare to Work and the Well-Being of Preschoolers and Adolescents”, Science 299, 15481552.

Cunha F. and J. Heckman (2007) “The Technology of Skill Formation” American Economic Review, vol. 97(2), 31-47.

Dustmann C. and U. Schonberg (2008) “The Effect of Expansions in Maternity Leave Coverage on Children’s Long-Term Outcomes”, IZA Discussion Paper No. 3605.

Fredriksson P. and B. Öckert (2006) "Is Early Learning Really More Productive? The Effect of School Starting Age on School and Labor Market Performance”, IFAU Working Paper 2006:12.

Gregg P., E. Washbrook, C. Propper and S. Burgess (2005) “The Effects of a Mother's Return to Work Decision on Child Development in the UK” Economic Journal 115 (February), F48-F80

Han W., J. Waldfogel and J. Brooks-Gunn (2001): “The Effects of Early Maternal Employment on Children's Later Cognitive and Behavioral Outcomes”, Journal of Marriage and the Family, 63-2, 336-354.

Haveman R., B. Wolfe and J. Spaulding (1991) “Childhood Events and Circumstances Influencing High School Completion”, Demography, 28-1, 133-157.

Harvey E. (1999) "Short-Term and Long-Term Effects of Early Parental Employment on Children of the National Longitudinal Survey of Youth”, Developmental Psychology, 35: 445-459. 
Heckman J. J. (2000) “Policies to Foster Human Capital”, Research in Economics, 54-1, 3-56.

Hill, M. S., and G. J. Duncan (1987) "Parental Family Income and the Socioeconomic Attainment of Children”, Social Science Research, 16-1, 39-73.

Horisch H. (2008) “Does Parental Employment Affect children’s Educational Attainment? Evidence from Germany”, Munich Economics Discussion Paper No. 2008-05.

Lalive R. and J. Zweimüller (2008) "Does Parental Leave Affect Fertility and Returnto-Work? Evidence from Two Natural Experiments” The Quarterly Journal of Economics, forthcoming.

Liu H., T. Mroz and W. Van der Klaauw (2008) "Maternal Employment, Migration, and Child Development”, forthcoming Journal of Econometrics.

Moore K. A. and A. K. Driscoll (1997) "Low-Wage Maternal Employment and Outcomes for Children: A Study”, Future of Children, 7-1, 122-127.

Parcel T. L. and E.G. Menaghan (1994) "Early Parental Work, Family Social Capital, and Early Childhood Outcomes”, American Journal of Sociology, 99-4, 972-1009.

Pettersson-Lidbom P. and P. Skogman-Thourise (2009) "Does child spacing affect children's outcomes? Evidence from a Swedish reform", IFAU Working Paper 2009:7.

Riksförsäkringsverket (2002) “Spelade pappamånaden någon roll? - Pappornas uttag av föräldrapenning” RFV Analyserar 2002:14, Riksförsäkringsverket.

Ruhm C. J. (2000) “Parental Leave and Child Health”, Journal of Health Economics, 19-6, 931-960.

Ruhm C. J. (2004) “Parental Employment and Child Cognitive Development”, Journal of Human Resources, 39-1, 155-192.

Schonkoff J. P. and D. A. Phillips (2000) From Neurons to Neighbourhoods: The Science of Early childhood Development. Washington DC, National Academy Press. 
SOU (2005) ”Reformerad föräldraförsäkring - Kärlek, omvårdnad, trygghet”, SOU 2005:73.

Sundström M. (1996) "Determinants of the use of parental leave benefits by women in Sweden in the 1980s” Scandinavian Journal of Social Welfare 5, 76-82.

Sundström M. and A.-Z. Duvander (2002) “Gender division of childcare and the sharing of parental leave among new parents in Sweden”, European Sociological Review, 18, 433-447.

Tanaka S. (2005) "Parental leave and child health across OECD countries” Economic Journal, 115 (February), p F7-F28.

Waldfogel J., W. J. Han, and J. Brooks-Gunn (2002) "The Effects of Early Maternal Employment on Child Cognitive Development”, Demography, 39-2, 369-392.

Wurtz A. (2007) “The Long-Term Effect on Children of Increasing the Length of Parents' Birth-Related Leave”, Aarhus School of Business, Department of Economics Working Paper No. 07-11. 


\section{Appendix A}

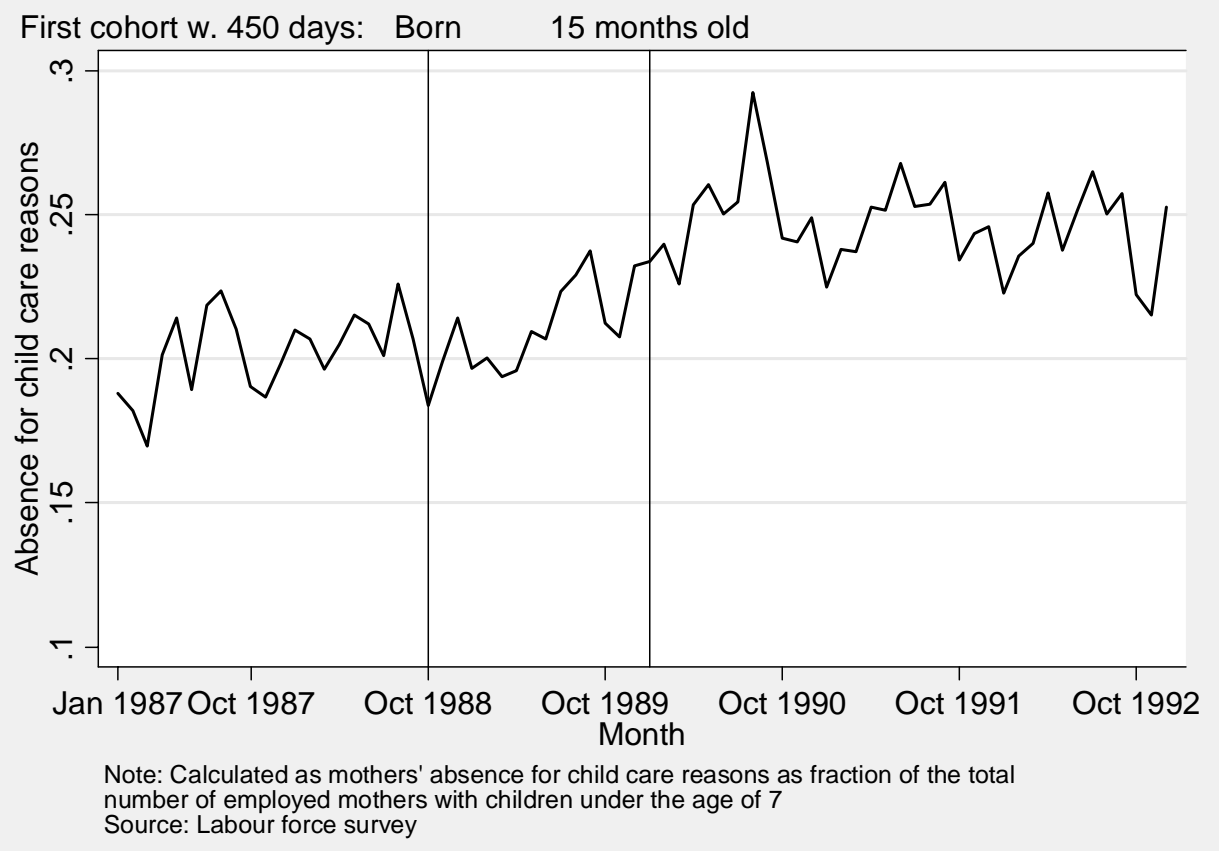

Figure A1 Percent of employed mothers of small children that were absent for child care reasons during the survey week (by month) 

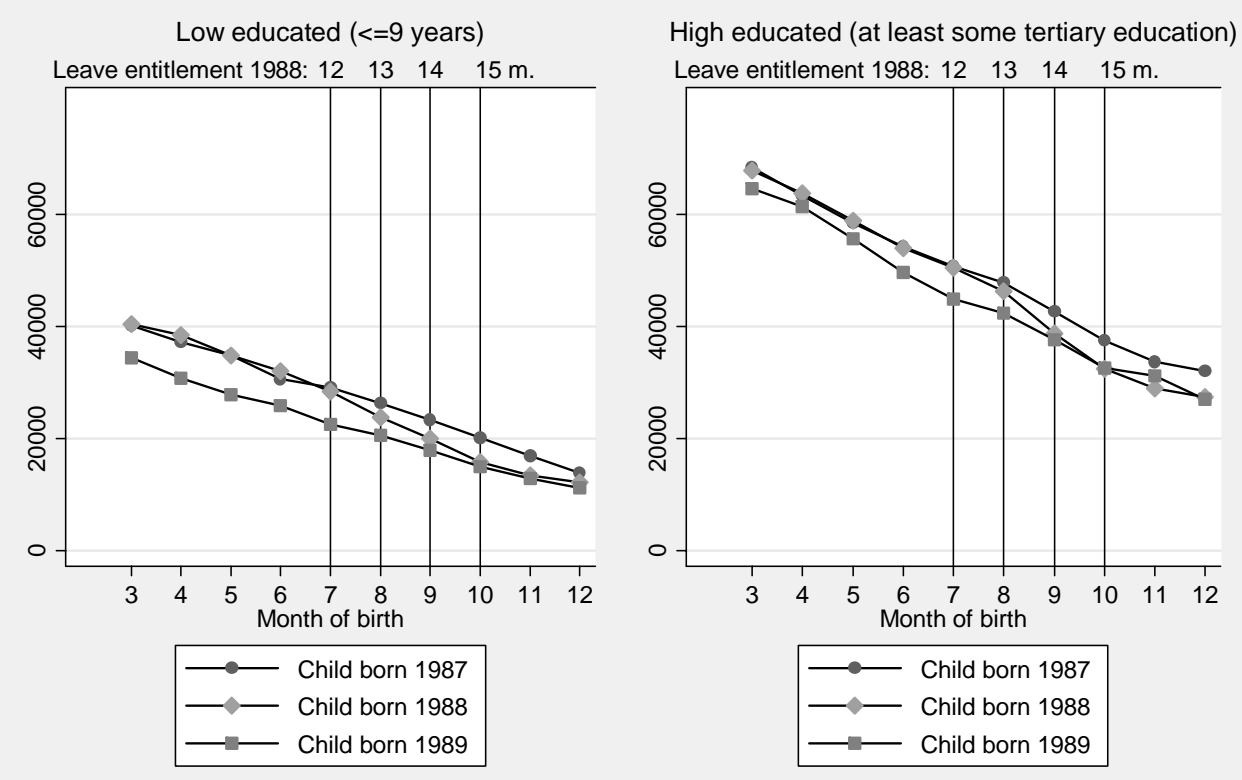

Note: Entitlement was 12 months before August 1988 and 15 months from October 1988 Earnings are during the full year after the year of child birth (i.e. during 1988, 1989 and 1990) Denoted in 1990 SEK

Figure A2 Mothers' real labor earnings by level of education during the full calendar year following childbirth - averages by month of childbirth 


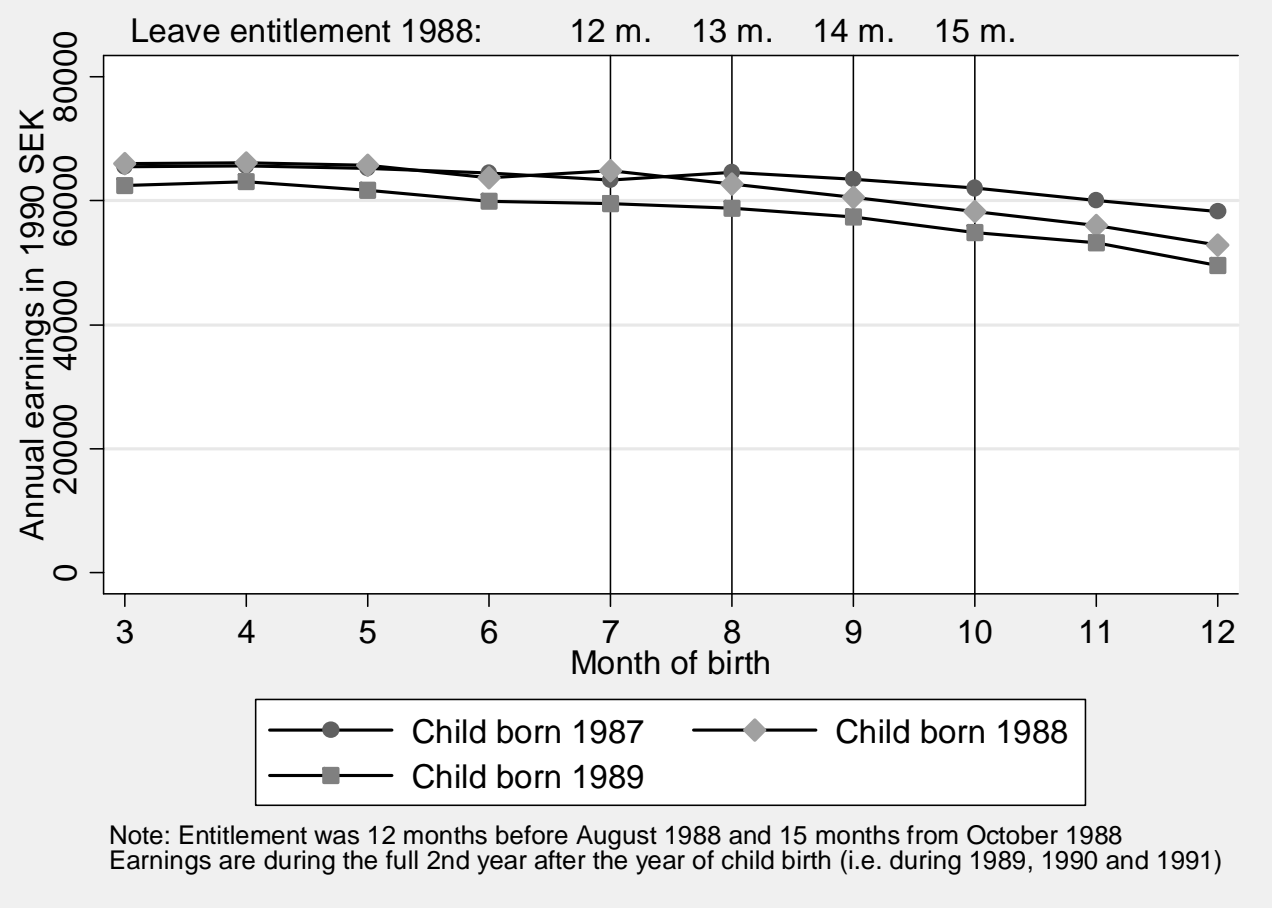

Figure A3 Mothers' real labor earnings by level of education during the second full calendar year following childbirth - averages by month of childbirth 